\title{
SOIL VARIABILITY IN DIFFERENT LANDSCAPE POSITIONS IN THE PORTO ALEGRE BOTANICAL GARDEN, SOUTHERN BRAZIL
}

\author{
Variabilidade de solos em posições distintas da paisagem no \\ Jardim Botânico de Porto Alegre, sul do Brasil
}

\author{
Luís Fernando da Silva ${ }^{1}$, Paulo César do Nascimento ${ }^{2}$, Alberto Vasconcellos Inda ${ }^{2}$, Edsleine Ribeiro Silva ${ }^{2}$
}

\begin{abstract}
Knowledge of soil characteristics in areas where activities related to the environment are developed, such as Porto Alegre Botanical Garden (JB-PoA), is a fundamental condition for the sustainable use of this natural resource. The objective of this study was to characterize, classify and evaluate some issues about soil formation in Porto Alegre Botanical Garden, as well as relate their distribution on the landscape according to environmental characteristics. For the morphological description and collecting samples four profiles were selected (P1 to P4), located in the summit-shoulder transition, backslope, footslope and toeslope, respectively. Granulometric distribution of the P1 and P3 profiles indicated sharp textural gradient, with presence of textural and "plânico" B horizons, respectively, according to Brazilian System of Soil Classification. There is predominance of low values of $\mathrm{pH}$, and low base saturation, with exception of $\mathrm{P} 4$, indicating probable deposition of solution material at this area. The Fed/Fes relationship was greater in the profile located in the summit-shoulder transition (P1), indicating higher weathering. The Feo/Fed relationship increased in P3 and P4 profiles, indicating greater participation of iron oxides of low crystallinity in reducing environment. The occurrence of some pedogenic processes may be inferred, like lessivage in P1 (Ultic Hapludalf), due to clay skins and higher values of fine clay:total clay relationship in subsurface; ferrolysis and gleization, by low $\mathrm{pH}$ value and high Feo/Fed relationship in E and EB horizons of P3 (Oxyaquic Hapludalf), being the last also present in P4 (Humaqueptic Endoaquent), indicating gleization occurrence.
\end{abstract}

Index terms: Soil-landscape relationship; pedogenic processes; lessivage; ferrolysis; gleization.

\section{RESUMO}

O conhecimento das características dos solos em áreas onde são desenvolvidas atividades relacionadas ao meio ambiente, como no Jardim Botânico de Porto Alegre (JB-PoA), é condição fundamental para o uso sustentável desse recurso natural. Objetivose, com este estudo, foi caracterizar, classificar e avaliar aspectos da formação dos solos do Jardim Botânico de Porto Alegre, bem como relacionar a sua distribuição na paisagem às características do ambiente. Para a descrição morfológica e coleta de amostras foram selecionados quatro perfis (P1 a P4) localizados, respectivamente, no terço superior, terço médio, sopé e planície de inundação. A granulometria dos perfis P1 e P3 indicou gradiente textural acentuado, com horizonte B textural e B plânico, respectivamente, segundo o Sistema Brasileiro de Classificação de Solos. A relação Fed/Fes foi maior no perfil do terço superior (P1), indicando maior intemperismo. Houve predomínio de baixos valores de $\mathrm{pH}$ e de distrofismo, com exceção do $\mathrm{P} 4$, indicando provável deposição de materiais em solução nessa área. A relação Feo/Fed aumentou nos perfis P3 e P4, com maior participação dos óxidos de ferro de baixa cristalinidade em ambiente redutor. Alguns processos de formação predominantes podem ser inferidos, como a lessivagem, pela cerosidade e maior relação argila fina:argila total em P1 (Argissolo); a ferrólise e gleização, pelo baixo valor de pH e alta relação Feo/Fed nos horizontes E e EB de P3 (Planossolo), sendo esta última também presente em P4 (Gleissolo), indicando ocorrência de gleização.

Termos para indexação: Relação solo-paisagem; processos pedogenéticos; lessivagem; ferrólise; gleização.

\section{INTRODUCTION}

Knowledge of the characteristics of natural resources in areas where are developed activities related to the environment is a fundamental condition for the sustainable use of these resources. In these, the soil occupies a prominent position, because it is expression of environmental factors related their formation (Buol et al., 2003). In areas for Environmental Conservation Unit, soil characterization constitutes a subsidy for planning in order to optimize the use of this resource within the inherent activities to these places. In the Porto Alegre Botanical Garden (JB-PoA), site where are carried out research activities of flora of the Rio Grande do Sul State (RS), environmental education, leisure and recreation, there are no detailed studies that investigate the soil characteristics of park associated with their formation environment.

In the city of Porto Alegre, preliminary soil survey (Schneider et al., 2008) identified, according to

\footnotetext{
${ }^{1}$ Universidade Federal do Rio Grande do Sul/UFRGS - Departamento de Solos - 91540-000 - Porto Alegre - RS - Brasil - luisf_agro@yahoo.com.br 2Universidade Federal do Rio Grande do Sul/UFRGS - Departamento de Solos - Porto Alegre - RS - Brasil

Received in april 14, 2015 and approved in june 2, 2015
} 
Brazilian System of Soil Classification (EMBRAPA, 2013), the occurrence of Argissolo on top and slope of hills with gently sloping relief; Cambissolo and Neossolo in granitic hills with moderately steep and steep relief; and Hydromorphic/Aluvial soils in low and floodplain areas. The steep relief of hill areas contributes to the formation of thinner soil and chemical characteristics which reflect a low weathering degree (Medeiros et al., 2013).

The insertion area of JB-PoA shows smooth relief and less steep than hill areas of Porto Alegre. The geomorphic characteristics indicate an area with knoll forms, with flat or convex summit positions, and more gentle slopes in relation to hill areas (Moura; Dias, 2012). These features are reflected in major water infiltration, resulting in deeply weathered soil profiles. Based on this knowledge, the hypothesis is that specific characteristics of relief and parent material of the study area imply in similarities with hill areas, but with formation processes in greater definition and intensity, resulting in soils with high degree of pedogenetic development. The objectives were: characterize and classify the representative soil profiles of the occurrence of taxonomic units in the JBPoA, according to Brazilian System of Soil Classification (EMBRAPA, 2013) and the Soil Taxonomy (Soil Survey Staff, 2010); and indicate the influence of soilenvironment relationship, through soil forming process of JB-PoA.

\section{MATERIAL AND METHODS}

The Porto Alegre Botanical Garden (JB-PoA) covers an area of 39 hectares, limited to the coordinates $30^{\circ} 02^{\prime} 51^{\prime \prime}$ and $30^{\circ} 03^{\prime} 20^{\prime \prime}(\mathrm{S})-51^{\circ} 10^{\prime} 19^{\prime \prime}$ and $51^{\circ} 10^{\prime} 51^{\prime \prime}(\mathrm{W})$ in the urban area of Porto Alegre (FZB, 2009). The weather is humid subtropical with a long-term average annual temperature of $19.5^{\circ} \mathrm{C}$ and long-term average annual rainfall of $1,300 \mathrm{~mm}$, with rainfall well distributed throughout the year. The long-term annual effective rainfall (precipitation minus evapotranspiration) is $430 \mathrm{~mm}$ (SEMA, 2010). The parent material is composed of "Gnaisse Porto Alegre" and "Alterito Serra de Tapes". The gneiss has dark color to black, with quartz, feldspars and biotite composition. The alterite was formed from coluvial deposits, consisting of kaolinite and iron oxides (Schneider et al., 2008). The local relief consists in smooth hills, with influence of aluvial terraces of the "Arroio Dilúvio".

To study the soil genesis were selected four profiles (Figure 1), located in the summit-shoulder transition (P1), sloping from 13 to $15 \%$; backslope (P2), sloping from 18 to $20 \%$; footslope (P3), sloping from 0 to $2 \%$; toeslope (P4), sloping from 2 to $3 \%$.

The trenches were opened to the description of the main pedogenetic horizons of the soil, according to methodology described by Santos et al. (2005). Horizons Bt3 (P1), Cr2 and $\mathrm{Cr} 3$ (P2), Btg2 (P3) and Cg2 (P4), were collected by auger. The soil samples were dried, ground and sieved in mesh $2 \mathrm{~mm}$ for separation of fine earth fraction dried in air (TFSA).

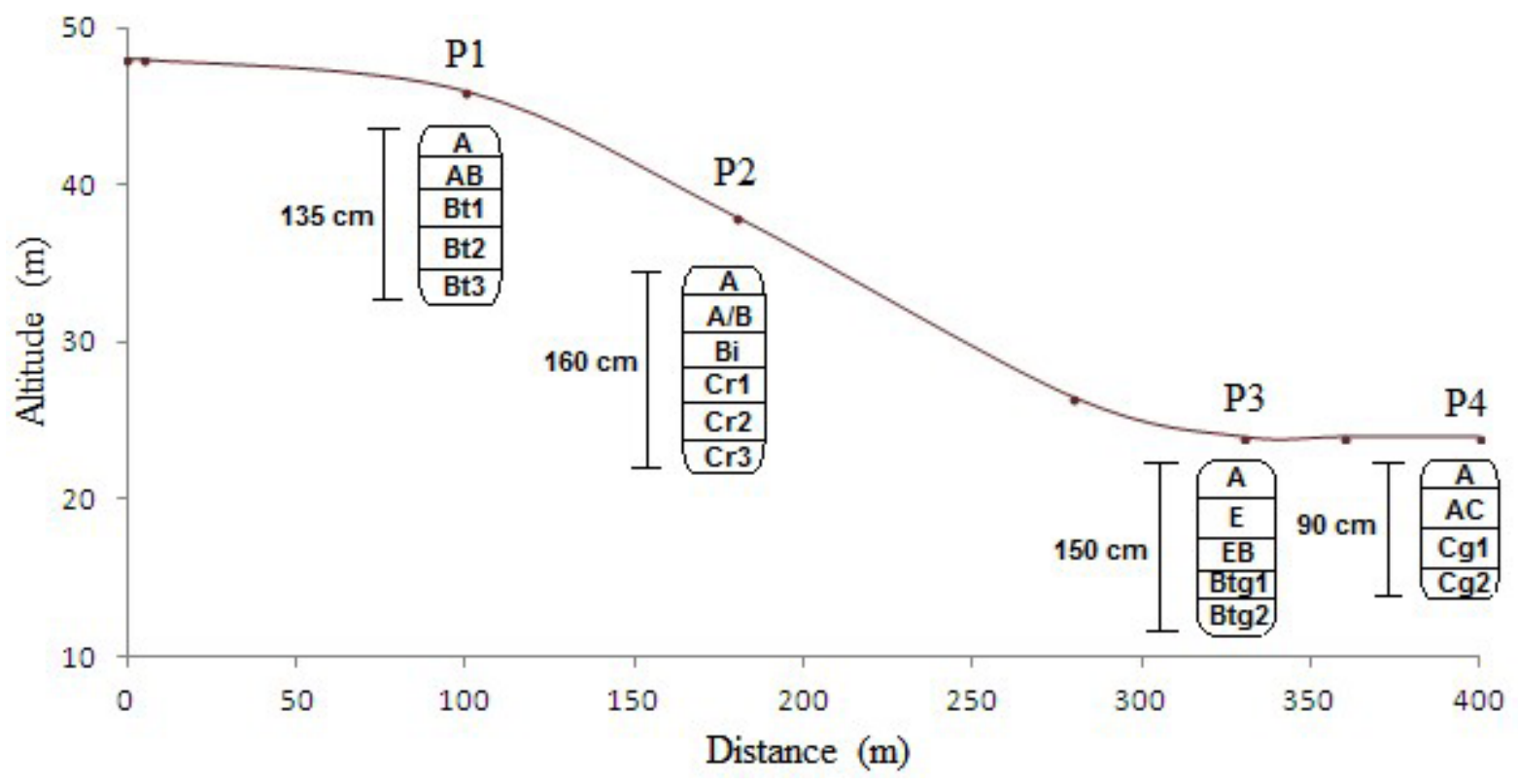

Figure 1: Schematic representation of topographic location of the study profiles. 
The granulometric distribution and clay dispersed in water were determined according to EMBRAPA(1997), while the fine clay fraction $(<0.2 \mu \mathrm{m})$ according to method of Jackson (1956). With these data were calculated the fine clay/total clay relationship (Claf/Cla) and soil flocculation (SoF). To identify possible lithologic discontinuities in the soil profiles were calculated fine sand/total sand relationship (FS/TS) and the uniformity value (VU) (Schaetzl, 1998).

In relation to chemical characteristics, the $\mathrm{pH}$ in water and $\mathrm{KCl}$, the exchangeable cations $\left(\mathrm{Ca}^{2+}, \mathrm{Mg}^{2+}, \mathrm{Na}^{+}\right.$, $\mathrm{K}^{+}$and $\left.\mathrm{Al}^{3+}\right)$, the potential acidity $\left(\mathrm{H}^{+}+\mathrm{Al}^{3+}\right)$ and the organic carbon content were determined according to EMBRAPA (1997). Were calculated cation exchange capacity (CEC), clay fraction activity (CFA) and base saturation (V). The sulfuric attack was carried out to quantify the $\mathrm{Fe}_{2} \mathrm{O}_{3}, \mathrm{Al}_{2} \mathrm{O}_{3}$ and $\mathrm{SiO}_{2}$ constituents of clay minerals (EMBRAPA, 1997). Selective dissolutions were performed to iron oxides with dithionite-citrate-bicarbonate (DCB) at $80^{\circ} \mathrm{C}$ by Mehra and Jackson (1960), and ammonium oxalate (OXA) according to Schwertmann (1964) to determine the Fe and Al content in pedogenic oxides (Fed; Ald) and low crystallinity (Feo, Alo). The content of the elements $\mathrm{Fe}, \mathrm{Si}$ and $\mathrm{Al}$ was determined by atomic absorption spectroscopy. With these data were calculated Ki index, Fed/Fes and Feo/Fed relationships, used to evaluate the soil weathering stage and the crystallinity degree of oxides (Kämpf; Curi; Marques, 2009).

Mineralogical composition was determined by $\mathrm{X}$-ray diffractometry analysis, conducted in sand, silt and clay granulometric fractions, with a Bruker-D2 Phaser equipment in non-oriented blades (powder samples). The samples were irradiated in the range from 4 to $40^{\circ} 2 \theta$, with a scan rate of $2^{\circ} 2 \theta \mathrm{min}^{-1}$. Halite was added as an internal standard for the measurements of the spacings in clay fraction. The results are interpreted according Brindley and Brown (1980).

\section{RESULTS AND DISCUSSION}

The soils developed significant variation of thickness (Table 1), being observed thicker solum in P1 (Ultic Hapludalf) and P3 (Oxyaquic Hapludalf). The greatest slope (20\%) in P2 (Oxic Dystrudept) influenced its low pedogenetic development compared to $\mathrm{P} 1$, through the low water infiltration, which resulted lower weathering in depth (Kämpf; Curi; Marques, 2009). This characteristic of $\mathrm{P} 2$ is evidenced by contact with $\mathrm{Cr}$ horizon less than $90 \mathrm{~cm}$ depth (Figure 2). The P4 profile (Humaqueptic Endoaquent) also showed lower development, having contact with the $\mathrm{Cg}$ horizon from $40 \mathrm{~cm}$ depth, which can be attributed to the stagnant water and lower weathering intensity in this landscape position.

In the profiles of upper portion of the landscape (P1 and P2) there are red and yellow colors (hues between 2.5YR and 7.5YR), which indicates the predominance of crystalline iron oxides as hematite $\left(\mathrm{Fe}_{2} \mathrm{O}_{3}\right)$ and goethite $(\mathrm{FeOOH})$ in good to moderate drainage conditions (Kämpf; Schwertamnn, 1983).

In the Bi horizon of $\mathrm{P} 2$, the more reddish (2.5YR $4 / 8$ ) and variegate colors (7.5YR 4/6) in condition of good drainage, indicated a weathered clay matrix, with presence of minerals that have a low stage of weathering (Schneider; Klamt; Giasson, 2007). Gray colors in the P3 and P4 profiles suggest the occurrence of anaerobic bacterial activity, which reduces soil oxidized compounds, resulting in low chroma related to iron mobility and occurrence of soil gleization (Ponnamperuma, 1972).

In the $\mathrm{Bt} 2$ horizon of $\mathrm{P} 1$, the presence of clay skins coating surface of aggregates and the blocky structure may be related to illuvial clays (Costa; Libardi, 1999). The surface horizons of the profiles studied showed weak or moderate structure, small to medium, granular or crumb, condition associated with increase of organic matter on the soil surface. The massive structure in the deeper horizons of P2 (Cr), P3 (Btg1) and P4 (Cg1) shows the little pedogenetic evolution.

The P1 and P3 profiles showed sharp textural gradient (Table 2). In the $\mathrm{P} 1$ profile, the $\mathrm{B} / \mathrm{A}$ textural relationship was 1.88 , classified as $\mathrm{B}$ textural horizon. In the $\mathrm{P} 3$ profile, the abrupt textural change between $\mathrm{EB}$ and Btg1 horizons, associated with hue 10YR and chroma lower or equal to 3 in the B horizon, classified it as B "plânico" horizon (EMBRAPA, 2013).

Unlike $\mathrm{P} 1$ and $\mathrm{P} 3$, the $\mathrm{P} 2$ and $\mathrm{P} 4$ profiles showed little textural variation between horizons. However, in P2 stood out the clayey texture compared to other landscape profiles, being possible the change in parent material. According to Teramoto, Lepsch and Vidal-Torrado (2001), marked differences in soil texture on a topographic transect may indicate the variation of parent material.

In all profiles the variation of fine sand/total sand relationship between horizons was lower than 0.14 , which combined with uniformity value (VU) lower than 0.60 , rule out possibility of lithologic discontinuity between horizons of each profile (Schaetzl, 1998). The P1 profile showed low soil flocculation in $\mathrm{A}$ and $\mathrm{AB}$ horizons, favoring the vertical transport of fine clay by water from eluvial A horizon and the deposition in illuvial B horizon, when the pores of smaller size are filled by clay (Almeida; Klamt; Kämpf, 1997; Santos et al., 2010). 
Table 1: Morphological attributes of Porto Alegre Botanical Garden soils.

Hor $^{(1)} \quad$ Depth, moist Munsell color, texture, structure, moist consistence, waxiness, transition

-(P1) Ultic Hapludalf-

A $\quad 0-15 \mathrm{~cm} ; 7.5$ YR 4/3 (moist); sandy loam; weak/moderate, small/medium, granular; very friable; slightly plastic and slightly sticky; gradual and plan boundary.

$\mathrm{AB} \quad$ 15-46 cm; 7.5YR 3/3 (moist); sandy clay loam; moderate, small/medium, subangular blocky; very friable; slightly plastic and sticky; gradual and plan boundary.

Bt1 46-68 cm; 7.5YR 4/6 (moist); clay loam; moderate, medium/big, subangular blocky; friable; plastic and sticky; clear and plan boundary.

Bt2 68-102 cm; 5YR 4/6 (moist); clay loam; moderate, medium/big, subangular blocky; friable; plastic and sticky; common and moderate waxiness.

Bt3 102-135+ cm (collected by auger); 5YR 4/6 with small and little mottle 10YR 5/6 (moist); clay loam/clay.

(P2) Oxic Dystrudept

A $\quad 0-25 / 30 \mathrm{~cm} ; 10$ YR 3/4 (moist); sandy clay loam; moderate, small, granular, moderate, small/medium, subangular blocky; very friable; slightly plastic and slightly sticky; clear and irregular boundary.

A/B 25/30-55/60 cm;2.5YR 4/8 with small and little mottle 10YR 3/6 (moist); clay loam; moderate, small/medium, subangular blocky; firm; slightly plastic and sticky; clear and wavy boundary.

Bi $\quad 55 / 60-80 / 85 \mathrm{~cm} ; 2.5 Y R$ 4/8 with variegate 7.5YR 4/6 (moist); clay loam; moderate, medium/big, subangular blocky; firm; slightly plastic and sticky; gradual and wavy boundary.

Cr1 80/85-120 cm; 5YR 5/8 (moist); sandy clay/sandy clay loam; massive, which breaks in subangular blocky; very friable; slightly plastic and slightly sticky.

Cr2 120-140 cm (collected by auger); 5YR 4/6 with small and little mottle 2.5Y 8/1 (moist); sandy clay/sandy clay loam.

Cr3 140-160+ cm (collected by auger); 7.5YR 8/4 (moist); sandy clay/sandy clay loam.

-(P3) Oxyaquic Hapludalf-

A $\quad 0-20 / 27 \mathrm{~cm}$; 10YR 3/3 (moist); loamy sand; moderate, small, granular, moderate, small/medium, subangular blocky; very friable; not plastic and not sticky; clear and wavy boundary.

E 20/27-60/62 cm; 10YR 4/4 (moist); sand; moderate, small, granular, moderate, small, subangular blocky; loose; not plastic and not sticky; gradual and plan/wavy boundary.

EB 60/62-105 cm; 7.5YR 4/3 (moist); sandy loam; moderate, medium/big, subangular blocky; friable; slightly plastic and slightly sticky; clear and plan boundary.

Btg1 105-120 cm; 10YR 4/3 (moist); sandy clay loam; massive; plastic and sticky.

Btg2 120-150+ cm (collected by auger); 10YR 6/1 with medium and abundant mottle 10YR 5/8 (moist); clay; firm; very plastic and sticky.

(P4) Humaqueptic Endoaquent

A $\quad 0-15 \mathrm{~cm} ; 7.5$ YR 3/2 (moist); sandy clay loam; crumb; very friable; not plastic and slightly sticky; clear and plan boundary.

AC 15-40 cm; 10YR 3/2 with small and little mottle 5YR 4/6 (moist); sandy clay loam; weak, medium, subangular blocky; friable; slightly plastic and slightly sticky; clear and plan boundary.

Cg1 40-60 cm; 10YR 3/1 (moist); sandy clay loam; massive; slightly plastic and slightly sticky.

Cg2 60-90+ cm (collected by auger); 10YR 4/2 with small and little mottle 10YR 5/6 (moist); clay loam; very plastic and sticky.

(1) Hor: horizon.

Ciênc. Agrotec., Lavras, v. 39, n. 5, p. 477-487, set./out., 2015 


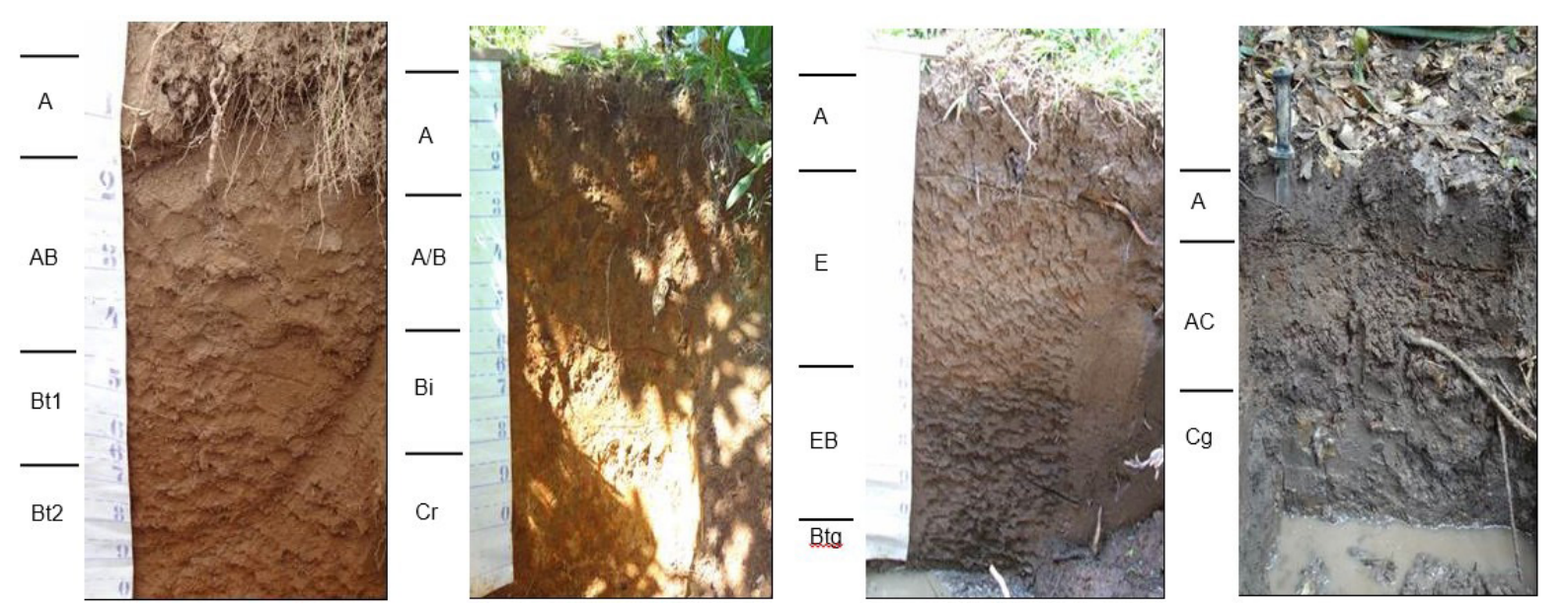

Figure 2: Looking from left to right, profile image of the Ultic Hapludalf (P1), Oxic Dystrudept (P2), Oxyaquic Hapludalf (P3) and Humaqueptic Endoaquent (P4), showing the variation of solum depth (depth of A and B horizons) related to soil development.

The occurrence of clay skins in the Bt horizon and increase of fine clay/total clay relationship from A horizon to Bt horizon indicated lessivage of clays in P1. Besides the low soil flocculation be a prerequisite to lessivage, according to Quénard et al. (2011) the translocation of clays is favored in humid weather (when the precipitation is higher than evapotranspiration at least $150 \mathrm{~mm}$ ) and in planar or sub-planar surfaces. Therefore, the humid weather of Porto Alegre and the location of P1 profile (summit-shoulder transition) in the landscape allow lessivage process.

The soil profiles showed low $\mathrm{pH}$ with values lower than 5.5 (Table 3). The $\mathrm{pH} \mathrm{KCl}$ are smaller than 5.0 in all profiles, and in conjunction with negative $\Delta \mathrm{pH}(\mathrm{pH} \mathrm{KCl}-$ $\mathrm{pH} \mathrm{H}_{2} \mathrm{O}$ ), indicate the absence of "ácrico" character and, therefore, the predominance of negative charges in all profiles (EMBRAPA, 2013). The higher base saturation found in the $\mathrm{A}$ and $\mathrm{Cg} 2$ horizons of $\mathrm{P} 4$ seems indicate the importance of the concave relief in the formation of eutrophic character, with the lateral movement of soluble cations by water flow, towards the upper third for the flood area. The CEC of clay fraction (CFA) of $\mathrm{B}$ or $\mathrm{C}$ horizons in all profiles was lower than $27 \mathrm{cmolc}^{-1}$, featuring soils with low clay activity.

In the $\mathrm{P} 3$ profile, besides the sharp acidity ( $\mathrm{pH}$ of 4.5 in water) in E and EB horizons, soil CEC is less than 4.0 cmolc kg-1. According to Brinkman (1970) the soil condition under successive cycles of wetting and drying favors the destruction of clay minerals by pedogenetic process of ferrolysis, resulting in horizons with low $\mathrm{pH}$, low clay content and low soil CEC, these characteristics found in P3. These results are similar to those obtained by
Mafra et al. (2001), noting that ferrolysis is manifested in sharp acidity ( $\mathrm{pH} 3.0$ to 4.0 ) and produces sandy horizons. Also in the $\mathrm{Cg} 1$ horizon of $\mathrm{P} 4$, low $\mathrm{pH}$ (4.4) associated with the lower clay content and exchangeable cations, even as high exchangeable aluminum content, may indicate an initial process of ferrolysis of clays in this profile section.

Barbiero et al. (2010) monitored changes in $\mathrm{pH}$ and electrical conductivity of soil at different times of the year to explain the occurrence of ferrolysis. During the rainy season, they observed an increase in the $\mathrm{pH}$ of soil solution due to reduction reactions that consume $\mathrm{H}^{+}$ions. At the end of the rainy season happened high weathering, resulting in low $\mathrm{pH}$, where oxidation reactions in soil produce $\mathrm{H}^{+}$ protons which penetrate the octahedral structure of clay minerals, destabilizing them.

The Fed/Fes relationship in all profiles showed values between 0.53 and 0.98 (Table 4), which indicates a moderate to advanced weathering for all soils. In the $\mathrm{P} 2$ profile, the high $\mathrm{Fed} / \mathrm{Fes}$ relationship in $\mathrm{A}, \mathrm{A} / \mathrm{B}$ and Bi horizons identifies front of weathering, with clear reduction in this value in $\mathrm{Cr} 1$ horizon less weathered. However, the $\mathrm{Cr} 3$ horizon showed an increase of Fed/Fes relationship (0.89), highlighting the sudden decrease in Fes content of $\mathrm{Cr} 3$. This data allows note small amount of iron in this horizon, which was observed in field descriptions through the light color and low chroma. Smaller values of Fed/Fes relationship in the surface horizons of P3 and P4 are related to lower oxidation environment and subject to lower rates of weathering (Pereira; Anjos, 1999; Santos et al., 2010). 
SILVA, L. F. da. et al.

Table 2: Physical attributes of Porto Alegre Botanical Garden soils.

\begin{tabular}{|c|c|c|c|c|c|c|c|c|c|c|}
\hline Hor & $\begin{array}{c}\text { Gra } \\
\%\end{array}$ & CS & FS & Silt & Clay & $\mathrm{FS} / \mathrm{TS}$ & \multirow[t]{2}{*}{ VU } & \multirow[t]{2}{*}{$\mathrm{Sil} / \mathrm{Cla}$} & \multirow[t]{2}{*}{$\begin{array}{c}\text { Claf/ } \\
\text { Cla }\end{array}$} & $\underset{\%}{\mathrm{SoF}}$ \\
\hline \multicolumn{8}{|c|}{ (P1) Ultic Hapludalf } & & & \\
\hline A & 5 & 396 & 284 & 150 & 170 & 0.42 & -0.41 & 0.88 & 0.60 & 29 \\
\hline $\mathrm{AB}$ & 4 & 251 & 249 & 220 & 280 & 0.50 & 0.04 & 0.79 & 0.69 & 11 \\
\hline Bt1 & 4 & 214 & 196 & 190 & 400 & 0.48 & -0.06 & 0.48 & 0.78 & 16 \\
\hline $\mathrm{Bt} 2$ & 3 & 181 & 159 & 190 & 470 & 0.47 & 0.22 & 0.40 & 0.77 & 21 \\
\hline Bt3 & 3 & 232 & 188 & 180 & 400 & 0.45 & - & 0.45 & 0.69 & 100 \\
\hline \multicolumn{11}{|c|}{ (P2) Oxic Dystrudept } \\
\hline A & 11 & 213 & 177 & 200 & 410 & 0.45 & -0.03 & 0.49 & 0.71 & 13 \\
\hline $\mathrm{A} / \mathrm{B}$ & 12 & 166 & 114 & 190 & 530 & 0.41 & 0.33 & 0.36 & 0.73 & 82 \\
\hline $\mathrm{Bi}$ & 17 & 181 & 69 & 180 & 570 & 0.28 & 0.51 & 0.32 & 0.67 & 97 \\
\hline $\mathrm{Cr} 1$ & 8 & 288 & 92 & 170 & 450 & 0.24 & -0.08 & 0.38 & 0.44 & 100 \\
\hline $\mathrm{Cr} 2$ & 8 & 246 & 74 & 170 & 510 & 0.23 & 0.14 & 0.33 & 0.56 & 94 \\
\hline $\mathrm{Cr} 3$ & 6 & 315 & 115 & 160 & 410 & 0.27 & - & 0.39 & 0.16 & 100 \\
\hline \multicolumn{11}{|c|}{ (P3) Oxyaquic Hapludalf } \\
\hline A & 1 & 478 & 262 & 160 & 100 & 0.35 & -0.32 & 1.60 & 0.61 & 30 \\
\hline $\mathrm{E}$ & 2 & 397 & 333 & 180 & 90 & 0.46 & 0.24 & 2.00 & 0.64 & 28 \\
\hline EB & 1 & 431 & 229 & 230 & 110 & 0.35 & -0.56 & 2.09 & 0.58 & 14 \\
\hline Btg1 & 1 & 232 & 178 & 360 & 230 & 0.43 & 0.23 & 1.57 & 0.58 & 9 \\
\hline Btg2 & 1 & 270 & 200 & 320 & 210 & 0.43 & - & 1.52 & 0.58 & 5 \\
\hline \multicolumn{11}{|c|}{ (P4) Humaqueptic Endoaquent } \\
\hline A & 2 & 288 & 232 & 270 & 210 & 0.45 & 0.09 & 1.29 & 0.67 & 26 \\
\hline $\mathrm{AC}$ & 5 & 307 & 223 & 270 & 200 & 0.42 & 0.26 & 1.35 & 0.70 & 33 \\
\hline $\mathrm{Cg} 1$ & 4 & 356 & 264 & 190 & 190 & 0.43 & -0.35 & 1.00 & 0.70 & 26 \\
\hline $\mathrm{Cg} 2$ & 4 & 240 & 190 & 280 & 290 & 0.44 & - & 0.97 & 0.58 & 3 \\
\hline
\end{tabular}

* Hor: horizon. Gra: gravel. CS: coarse sand. FS: fine sand. VU: uniformity value $=\left\{[(\mathrm{Silt}+\mathrm{FS}) /(\mathrm{TS}-\mathrm{FS})]_{\text {SURFACE HORIZON }} /[(\mathrm{Silt}+\mathrm{FS}) /\right.$ (TS-FS) $\left.]_{\text {SUBSURFACE HORIzoN }}\right\}-1,0$. FS/TS: fine sand/total sand relationship. Sil/Cla: silt/clay relationship. Claf/Cla: fine clay/total clay relationship. SoF: soil flocculation.

The Ki index in all profiles was higher than 3.0, not agreeing with values of low clay activity and Fed/Fes relationship moderate to high, that confirm a moderate to advanced weathering for all soils. An explanation for the high $\mathrm{Ki}$ index observed in all profiles is the solubilization of silicon from silt and sand fractions, indicating inadequate extraction method for soils with high quartz content in these fractions (Oliveira, 2011). The high Ki index in P3 reinforces this hypothesis, given the fact that the silt and sand fractions have significant participation in soil texture. Remarks of this condition were cited in Rolim Neto et al. (2009), Medeiros et al. (2013), and Nascimento, Lani and Zoffoli (2013).
In $\mathrm{P} 1$ and $\mathrm{P} 2$, the Feo/Fed relationship was equal or less than 0.1 , indicating the predominance of crystalline forms such as hematite and goethite (Pereira; Anjos, 1999; Meireles et al., 2012). This condition is coherent with the soil location in landscape, because they are located in upper positions and good drainage, therefore favorable condition for formation of crystalline oxides.

The higher values of Feo/Fed relationship were observed in $\mathrm{P} 3$ and $\mathrm{P} 4$, indicating greater participation of low crystallinity iron oxides, which represents an environment with poor drainage and favorable to pedogenetic process of gleization (Costa; Bigham, 2009). In the Btg2 and Cg2 
horizons of $\mathrm{P} 3$ and $\mathrm{P} 4$, respectively, it perceives a decrease of $\mathrm{Feo} / \mathrm{Fed}$ relationship, indicating greater participation of crystalline forms of iron oxides, which can be attributed to the presence of mottles in these horizons.

Duarte et al. (2000) observed these decreasing values in profiles with poor drainage, because the iron minerals precipitated in mottles had higher degree of crystallinity than those located in the soil matrix. In the EB horizon of P3, the high values of Feo/Fed (0.60) and Alo/ Ald (0.50) may be related to the existence of temporary water table in this profile section, with the interference of ferrolysis in the low crystallinity of iron oxides and aluminosilicates, above of the clayey Btg1 horizon (Coelho; Vidal-Torrado, 2003).

The X-ray diffraction (Figure 3 ) in the sand and silt of P1, P2, P3, and similarly P4 (data not shown) showed the occurrence of feldspar and quartz, with higher occurrence of feldspar in P2. The predominance of kaolinite in the clay fraction of all soils is related to an environment with moderate to advanced weathering, which was confirmed by low clay CEC. The presence of mica reflections in the clay of P2 indicated that the steep position occupied in the landscape (transition to steep slope relief) caused the lower weathering compared to other soils.

Table 3: Chemical attributes of Porto Alegre Botanical Garden soils.

\begin{tabular}{|c|c|c|c|c|c|c|c|c|c|c|c|c|c|c|}
\hline \multirow{3}{*}{ Hor } & \multicolumn{2}{|c|}{$\mathrm{pH}$} & \multirow[b]{2}{*}{$\mathrm{Ca}^{2+}$} & \multirow[b]{2}{*}{$\mathrm{Mg}^{2+}$} & \multirow[b]{2}{*}{$\mathrm{K}^{+}$} & \multirow{2}{*}{$\begin{array}{l}-- \text { Sor } \\
\mathrm{Na}^{+}\end{array}$} & \multirow{3}{*}{\multicolumn{2}{|c|}{$\begin{array}{l}\text { on complex--- } \\
\mathrm{SB} \quad \mathrm{H}+\mathrm{Al}\end{array}$}} & \multirow[b]{2}{*}{$\mathrm{Al}^{3+}$} & \multirow[b]{2}{*}{ CEC } & \multirow{3}{*}{ CFA } & \multirow{2}{*}{ V } & \multirow{2}{*}{$\mathrm{m}$} & \multirow{3}{*}{$\begin{array}{l}\mathrm{SOC} \\
\mathrm{g} \mathrm{kg}^{-1}\end{array}$} \\
\hline & $\mathrm{H}_{2} \mathrm{O}$ & $\mathrm{KCl}$ & & & & & & & & & & & & \\
\hline \multirow{2}{*}{\multicolumn{15}{|c|}{ (P1) Ultic Hapludalf }} \\
\hline & & & & & & & & & & & & & & \\
\hline A & 5.2 & 4.2 & 1.3 & 0.6 & 0.26 & 0.02 & 2.18 & 2.6 & 0.2 & 4.78 & 28 & 46 & 8 & 9.7 \\
\hline $\mathrm{AB}$ & 5.2 & 4.1 & 2.0 & 0.5 & 0.20 & 0.02 & 2.72 & 3.0 & 0.6 & 5.72 & 20 & 47 & 18 & 5.0 \\
\hline Bt1 & 5.0 & 3.8 & 1.4 & 0.7 & 0.21 & 0.01 & 2.32 & 4.5 & 1.8 & 6.82 & 17 & 34 & 44 & 4.9 \\
\hline $\mathrm{Bt} 2$ & 4.9 & 4.0 & 1.1 & 1.2 & 0.10 & 0.02 & 2.42 & 3.0 & 1.1 & 5.42 & 12 & 44 & 31 & 2.2 \\
\hline Bt3 & 5.0 & 3.9 & 1.1 & 1.3 & 0.09 & 0.02 & 2.51 & 3.1 & 1.2 & 5.61 & 14 & 45 & 32 & 1.8 \\
\hline \multicolumn{15}{|c|}{ (P2) Oxic Dystrudept } \\
\hline A & 5.2 & 4.3 & 2.5 & 1.8 & 0.73 & 0.03 & 5.06 & 3.9 & 0.5 & 8.96 & 22 & 57 & 9 & 12.0 \\
\hline $\mathrm{A} / \mathrm{B}$ & 4.9 & 3.9 & 1.8 & 1.5 & 0.62 & 0.03 & 3.95 & 4.7 & 2.1 & 8.65 & 16 & 46 & 34 & 8.5 \\
\hline $\mathrm{Bi}$ & 4.9 & 3.9 & 1.2 & 1.6 & 0.30 & 0.03 & 3.13 & 4.5 & 2.6 & 7.63 & 13 & 41 & 46 & 2.5 \\
\hline $\mathrm{Cr} 1$ & 5.0 & 3.9 & 0.7 & 1.2 & 0.11 & 0.03 & 2.04 & 3.8 & 2.2 & 5.84 & 13 & 34 & 52 & 1.3 \\
\hline $\mathrm{Cr} 2$ & 4.9 & 3.8 & 0.5 & 1.1 & 0.09 & 0.03 & 1.72 & 4.3 & 3.0 & 6.02 & 12 & 28 & 64 & 2.7 \\
\hline $\mathrm{Cr} 3$ & 5.0 & 3.9 & 0.5 & 1.0 & 0.08 & 0.02 & 1.60 & 2.8 & 2.7 & 4.40 & 11 & 36 & 63 & 1.0 \\
\hline \multicolumn{15}{|c|}{ (P3) Oxyaquic Hapludalf } \\
\hline A & 4.9 & 3.8 & 0.6 & 0.3 & 0.10 & 0.01 & 1.01 & 3.2 & 0.8 & 4.21 & 42 & 24 & 44 & 6.8 \\
\hline $\mathrm{E}$ & 4.5 & 3.7 & 0.4 & 0.1 & 0.04 & 0.01 & 0.55 & 2.6 & 1.1 & 3.15 & 35 & 19 & 65 & 1.7 \\
\hline EB & 4.5 & 3.8 & 0.4 & 0.1 & 0.05 & 0.02 & 0.57 & 2.8 & 1.0 & 3.37 & 28 & 18 & 63 & 2.3 \\
\hline Btg1 & 4.8 & 3.7 & 0.7 & 0.4 & 0.05 & 0.04 & 1.19 & 3.2 & 1.1 & 4.39 & 20 & 27 & 48 & 3.2 \\
\hline Btg2 & 5.1 & 3.7 & 1.2 & 1.3 & 0.08 & 0.10 & 2.68 & 1.7 & 0.6 & 4.38 & 21 & 61 & 18 & 0.8 \\
\hline \multicolumn{15}{|c|}{ (P4) Humaqueptic Endoaquent } \\
\hline A & 5.4 & 4.8 & 6.6 & 1.5 & 0.13 & 0.22 & 8.45 & 3.3 & 0.1 & 11.75 & 56 & 72 & 1 & 27.0 \\
\hline $\mathrm{AC}$ & 4.8 & 4.0 & 2.3 & 0.7 & 0.10 & 0.15 & 3.25 & 5.0 & 0.4 & 8.25 & 41 & 40 & 11 & 18.0 \\
\hline $\mathrm{Cg} 1$ & 4.4 & 3.6 & 0.9 & 0.5 & 0.13 & 0.07 & 1.60 & 3.6 & 0.9 & 5.20 & 27 & 31 & 36 & 6.3 \\
\hline $\mathrm{Cg} 2$ & 5.7 & 4.6 & 1.9 & 1.8 & 0.23 & 0.11 & 4.04 & 1.2 & 0.1 & 5.24 & 18 & 77 & 2 & 2.6 \\
\hline
\end{tabular}

* Hor: horizon; SB: sum of exchangeable bases; CEC: cation exchange capacity in pH 7.0; CFA: clay fraction activity; V: base saturation; m: aluminum saturation; SOC: soil organic carbon. 
Table 4: Content of sulfuric attack oxides $\left(\mathrm{Fe}_{2} \mathrm{O}_{3}, \mathrm{SiO}_{2}, \mathrm{Al}_{2} \mathrm{O}_{3}\right)$, oxides extracted by dithionite-citrate-bicarbonate $\left(\mathrm{Fe}_{2} \mathrm{O}_{3}, \mathrm{Al}_{2} \mathrm{O}_{3}\right)$, oxides extracted by ammonium oxalate $\left(\mathrm{Fe}_{2} \mathrm{O}_{3}, \mathrm{Al}_{2} \mathrm{O}_{3}\right)$, and relationship between them.

\begin{tabular}{|c|c|c|c|c|c|c|c|c|c|c|c|}
\hline \multirow[b]{2}{*}{ Hor } & \multicolumn{3}{|c|}{$\begin{array}{c}\text {----Oxides by sulfuric---- } \\
\text { attack }\end{array}$} & \multirow[b]{2}{*}{$\mathrm{Ki}$} & \multicolumn{2}{|c|}{ DCB } & \multicolumn{2}{|c|}{ OXA } & \multicolumn{3}{|c|}{ Relationship } \\
\hline & $\mathrm{Fe}_{2} \mathrm{O}_{3}$ & $\begin{array}{r}\mathrm{SiO}_{2} \\
-\mathrm{g} \mathrm{kg}^{-1}\end{array}$ & $\mathrm{Al}_{2} \mathrm{O}_{3}$ & & $\mathrm{Fe}_{2} \mathrm{O}_{3} \mathrm{~d}$ & $\mathrm{Al}_{2} \mathrm{O}_{3} \mathrm{~d}$ & $\begin{array}{l}\mathrm{Fe}_{2} \mathrm{O}_{3} \mathrm{O} \\
\mathrm{g}^{-1}\end{array}$ & $\mathrm{Al}_{2} \mathrm{O}_{3} \mathrm{O}$ & $\begin{array}{l}\mathrm{Feo} / \\
\mathrm{Fed}\end{array}$ & $\begin{array}{l}\text { Alo/ } \\
\text { Ald }\end{array}$ & $\begin{array}{c}\mathrm{Fed} / \\
\text { Fes }\end{array}$ \\
\hline \multicolumn{12}{|c|}{ (P1) Ultic Hapludalf } \\
\hline A & 10.3 & 44.4 & 21.6 & 3.50 & 8.7 & 4.8 & 1.3 & 1.2 & 0.15 & 0.25 & 0.84 \\
\hline $\mathrm{AB}$ & 18.1 & 97.6 & 46.1 & 3.60 & 17.7 & 9.6 & 1.7 & 2.9 & 0.10 & 0.30 & 0.98 \\
\hline Bt1 & 30.6 & 166.0 & 82.3 & 3.43 & 21.9 & 13.2 & 2.2 & 4.3 & 0.10 & 0.33 & 0.72 \\
\hline Bt2 & 35.8 & 194.1 & 105.0 & 3.14 & 27.6 & 14.2 & 2.3 & 4.3 & 0.08 & 0.30 & 0.77 \\
\hline Bt3 & 26.0 & 171.3 & 78.4 & 3.71 & 20.4 & 10.7 & 2.1 & 3.9 & 0.10 & 0.36 & 0.78 \\
\hline \multicolumn{12}{|c|}{ (P2) Oxic Dystrudept } \\
\hline A & 27.5 & 163.5 & 72.0 & 3.86 & 22.0 & 11.1 & 2.0 & 3.8 & 0.09 & 0.34 & 0.80 \\
\hline $\mathrm{A} / \mathrm{B}$ & 42.2 & 221.4 & 111.1 & 3.39 & 39.1 & 15.7 & 2.4 & 4.8 & 0.06 & 0.31 & 0.93 \\
\hline $\mathrm{Bi}$ & 40.5 & 223.4 & 122.5 & 3.10 & 32.0 & 13.3 & 2.5 & 4.9 & 0.08 & 0.37 & 0.79 \\
\hline $\mathrm{Cr} 1$ & 29.8 & 195.5 & 101.1 & 3.29 & 17.3 & 7.2 & 1.4 & 3.2 & 0.08 & 0.44 & 0.58 \\
\hline $\mathrm{Cr} 2$ & 25.0 & 192.7 & 98.1 & 3.34 & 18.4 & 8.7 & 1.7 & 3.3 & 0.09 & 0.38 & 0.74 \\
\hline $\mathrm{Cr} 3$ & 7.3 & 100.3 & 49.1 & 3.47 & 6.5 & 4.6 & 0.6 & 1.4 & 0.09 & 0.30 & 0.89 \\
\hline \multicolumn{12}{|c|}{ (P3) Oxyaquic Hapludalf } \\
\hline A & 8.1 & 37.6 & 13.7 & 4.66 & 7.0 & 3.3 & 1.6 & 0.8 & 0.23 & 0.24 & 0.86 \\
\hline E & 7.4 & 38.5 & 16.6 & 3.95 & 6.1 & 3.2 & 1.5 & 0.9 & 0.25 & 0.28 & 0.82 \\
\hline $\mathrm{EB}$ & 7.9 & 48.9 & 16.1 & 5.15 & 7.5 & 3.6 & 4.5 & 1.8 & 0.60 & 0.50 & 0.95 \\
\hline Btg1 & 19.8 & 77.1 & 37.5 & 3.50 & 12.4 & 5.3 & 3.7 & 1.6 & 0.30 & 0.30 & 0.63 \\
\hline Btg2 & 25.5 & 83.6 & 32.3 & 4.40 & 16.6 & 3.7 & 2.7 & 0.5 & 0.16 & 0.14 & 0.65 \\
\hline \multicolumn{12}{|c|}{ (P4) Humaqueptic Endoaquent } \\
\hline A & 20.8 & 87.0 & 35.6 & 4.16 & 16.9 & 5.1 & 8.9 & 2.1 & 0.53 & 0.41 & 0.81 \\
\hline $\mathrm{AC}$ & 16.6 & 70.9 & 39.0 & 3.09 & 12.6 & 4.6 & 4.7 & 1.8 & 0.37 & 0.39 & 0.76 \\
\hline $\mathrm{Cg} 1$ & 13.3 & 79.4 & 42.3 & 3.19 & 7.5 & 4.0 & 2.9 & 1.7 & 0.39 & 0.43 & 0.56 \\
\hline $\mathrm{Cg} 2$ & 17.9 & 119.9 & 67.1 & 3.04 & 9.5 & 5.5 & 2.0 & 2.1 & 0.21 & 0.38 & 0.53 \\
\hline
\end{tabular}

* Ki: relationship $\left(1.7 * \mathrm{SiO}_{2}\right) / \mathrm{Al}_{2} \mathrm{O}_{3}$. Feo: $\mathrm{Fe}_{2} \mathrm{O}_{3}$ extracted by ammonium oxalate. Alo: $\mathrm{Al}_{2} \mathrm{O}_{3}$ extracted by ammonium oxalate. Fed: $\mathrm{Fe}_{2} \mathrm{O}_{3}$ extracted by dithionite-citrate-bicarbonate. Ald: $\mathrm{Al}_{2} \mathrm{O}_{3}$ extracted by dithionite-citrate-bicarbonate. Fes: $\mathrm{Fe}_{2} \mathrm{O}_{3}$ extracted by sulfuric attack.

The P1 profile, with $\mathrm{B}$ textural horizon was classified as Argissolo Vermelho-Amarelo Distrófico típico (EMBRAPA, 2013), being classified as Ultic Hapludalf in the Soil Taxonomy (Soil Survey Staff, 2010). The attributes of $\mathrm{P} 2$ profile did not suggest a more developed formation process, and the occurrence of $\mathrm{B}$ incipiente horizon was decisive to classify it as Cambissolo Háplico Tb Distrófico típico, being classified as Oxic Dystrudept.
In the P3 profile, the presence of B "plânico" diagnostic horizon, according EMBRAPA (2013), defined the occurrence of Planossolo Háplico Distrófico gleissólico, being classified as Oxyaquic Hapludalf. In the P4 profile, the presence of glei horizon and organic carbon content suitable for A "húmico" horizon (EMBRAPA, 2013), defined as Gleissolo Melânico Tb Eutrófico típico, being classified as Humaqueptic Endoaquent. 

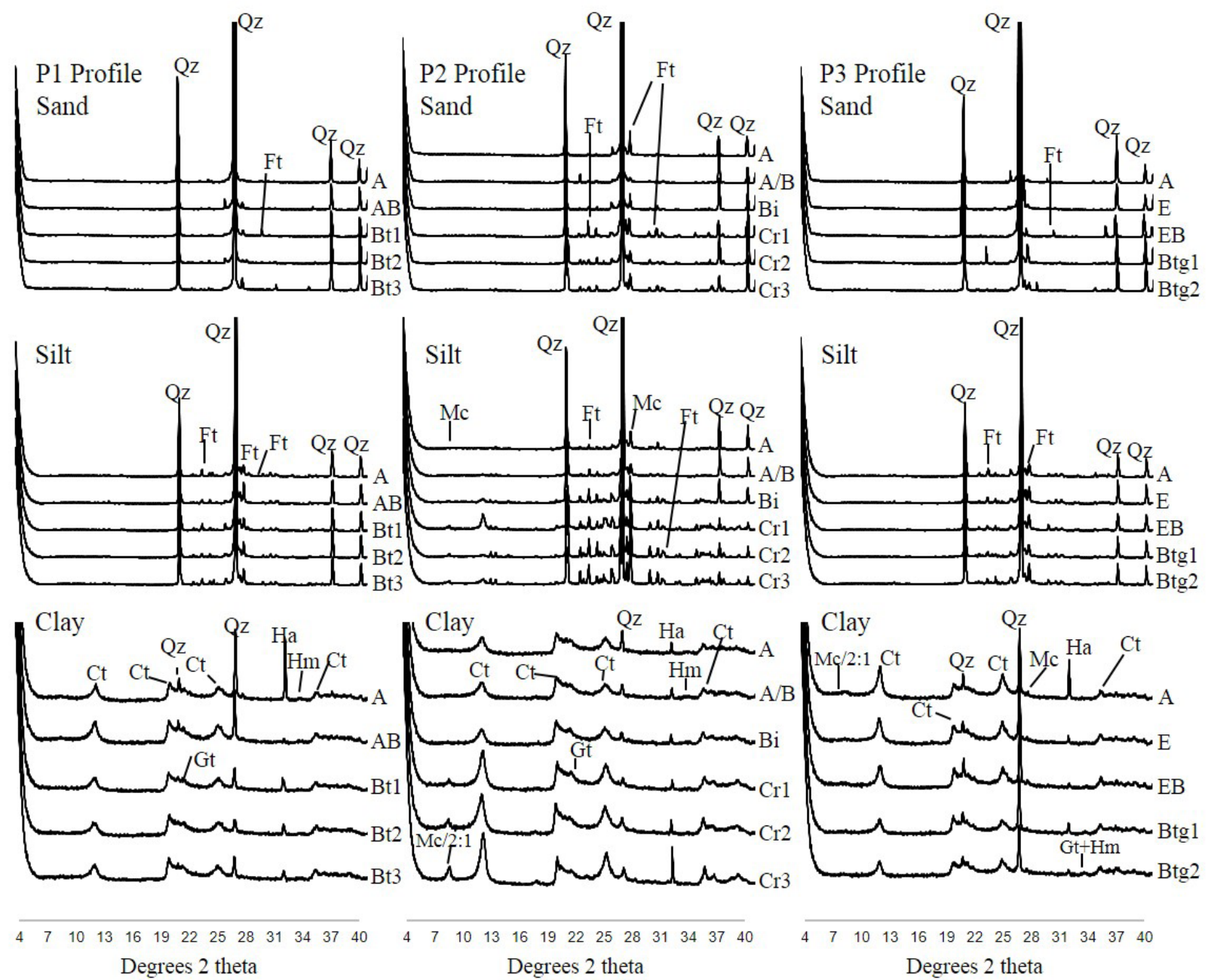

Figure 3: X-ray diffraction of sand, silt and clay of the pedogenetic horizons of P1, P2 and P3. Qz - quartz; Ft feldspar; Mc - mica; 2:1 - clay minerals 2:1; Ct - kaolinite; Gt - goethite; Hm - hematite; Ha - halite.

\section{CONCLUSIONS}

The soil distribution in the landscape of the Porto Alegre Botanical Garden followed the form observed in hill and knoll areas of Porto Alegre, with major pedogenic development in P1 (depth, soil forming process development), whereas incipient soil development occurred in P2, in condition of steep slope, which was corroborated by high presence of feldspar and mica. It is believed that steep slope implies lower infiltration of water in this landscape position, affecting the clay translocation in depth (non-occurrence of lessivage) or the progress of other soil forming processes.
The good drainage in summit-shoulder transition and backslope, and the sharp hydromorphism in footslope and toeslope positions, showed the influence of the relief forms in the soil genesis, which was corroborated by attributes like soil color and degree of crystallinity of iron oxides. The highest degree of soil weathering was observed in P1 located in upper third of landscape, not in steep slope, which was confirmed by the high Fed/Fes relationship.

The lessivage process could be inferred in P1 by clay skins and increase of fine clay/total clay relationship until the beginning of illuvial horizon; while the ferrolysis and gleization processes were indicated by low $\mathrm{pH}$ and high $\mathrm{Feo} / \mathrm{Fed}$ relationship in $\mathrm{E}$ and $\mathrm{EB}$ horizons of $\mathrm{P}$ 3, being the last also present in $\mathrm{P} 4$, indicating occurrence of gleization. 


\section{ACKNOWLEDGMENTS}

To "Fundação Zoobotânica" of Rio Grande do Sul State (FZB-RS), for supporting the study. To biologist Robberson Setubal and agronomist Walmir Gamboa, for their efforts to carry out the work. To "Conselho Nacional de Desenvolvimento Científico e Tecnológico" (CNPq 471446/2012-2) and "Coordenação de Aperfeiçoamento de Pessoal de Nível Superior" (CAPES), for the financial support and scholarship to the first author.

\section{REFERENCES}

ALMEIDA, J. A.; KLAMT, E.; KÄMPF, N. Gênese do contraste textural e da degradação do horizonte B de um Podzólico Vermelho-Amarelo da Planície Costeira do Rio Grande do Sul. Revista Brasileira de Ciência do Solo. 21(2):221-233, 1997.

BARBIERO, L. et al. Ferrolysis induced soil transformation by natural drainage in Vertisols of subhumid South India. Geoderma. 156(3):173-188, 2010.

BRINDLEY, G. W.; BROWN, G. Crystal structures of clay minerals and their $\mathrm{X}$-ray identification. London: Mineralogical Society, 1980. 495p.

BRINKMAN, R. Ferrolysis, a hydromorphic soil forming process. Geoderma. 3(3):199-206, 1970.

BUOL, S. W. et al. Soil Genesis and Classification. Yowa: Blackwell Publishing, 2003. 494p.

COELHO, M. R.; VIDAL-TORRADO, P. Caracterização e gênese de perfis plínticos desenvolvidos de arenito do Grupo Bauru: I - química. Revista Brasileira de Ciência do Solo. 27(3):483-494, 2003.

COSTA, A. C. S.; BIGHAM, J. M. Óxidos de ferro. In: ALLEONI, L. R. F.; MELO, V. F. (Eds.). Química e mineralogia do solo. Viçosa: Sociedade Brasileira de Ciência do Solo, 2009. p.506-520.

COSTA, A. C. S.; LIBARDI, P. L. Caracterização físico-hídrica de um perfil de terra roxa estruturada latossólica pelo método do perfil instantâneo. Revista Brasileira de Ciência do Solo. 23(3):669-677, 1999.

DUARTE, M. N. et al. Mineralogia, química e micromorfologia de solos de uma microbacia nos
Tabuleiros Costeiros do Espírito Santo. Pesquisa

Agropecuária Brasileira. 35(6):1237-1250, 2000.

EMPRESA BRASILEIRA DE PESQUISA AGROPECUÁRIA - EMBRAPA. Manual de métodos de análise de solo. 2.ed. Rio de Janeiro, 1997. 212p.

Sistema Brasileiro de Classificação de Solos. 3.ed. Brasília, 2013. 353p.

FUNDAÇÃO ZOOBOTÂNICA DO RIO GRANDE DO SUL - FZB. Jardim Botânico de Porto Alegre: 50 anos conservando a flora gaúcha. Porto Alegre: Jardim Botânico de Porto Alegre, 2009. 72p. (Publicações Avulsas FZB, 15).

JACKSON, M. L. Soil chemical analysis: advanced course. Madison: University of Wisconsin, 1956. 894p.

KÄMPF, N.; CURI, N.; MARQUES, J. J. Intemperismo e ocorrência de minerais no ambiente do solo. In: ALLEONI, L. R. F.; MELO, V. F. (Eds.). Química e mineralogia do solo. Viçosa: Sociedade Brasileira de Ciência do Solo, 2009. p.334-371.

KÄMPF, N.; SCHWERTMANN, U. Goethite and hematite in a climosequence in Southern Brasil and their application in classification of kaolinitic soils. Geoderma. 29(1):27-39, 1983.

MAFRA, A.L. et al. Pedogênese de uma seqüência de solos desenvolvidos de arenito na região de Piracicaba (SP). Revista Brasileira de Ciência do Solo. 25(2):355-369, 2001.

MEDEIROS, P. S. C. et al. Caracterização e classificação de solos graníticos em topossequência na região sul do Brasil. Ciência Rural. 43(7):1210-1217, 2013.

MEHRA, O. P.; JACKSON, M. L. Iron oxide removal from soils and clays by a dithionite-citrate system buffered with sodium bicarbonate. In: ADA, S. (Ed.). Clays clay mineralogy. Elmsdorf: Pergamon Press, 1960. p.317-342.

MEIRELES, H. T. et al. Relações solo-paisagem em topossequência de origem basáltica. Pesquisa Agropecuária Tropical. 42(2):129-136, 2012. 
MOURA, N. S. V.; DIAS, T. S. Elaboração do mapa geomorfológico do município de Porto Alegre - RS. Ciência e Natura. 34(2):113-138, 2012.

NASCIMENTO, P. C.; LANI, J. L.; ZOFFOLI, H. J. O. Caracterização, classificação e gênese de solos hidromórficos em regiões litorâneas no Estado do Espírito Santo. Científica. 41(1):82-93, 2013.

OLIVEIRA, J. B. Pedologia aplicada. 4.ed. Jaboticabal: FEALQ, 2011. 414p.

PEREIRA, M. G.; ANJOS, L. H. C. Formas extraíveis de ferro no Estado do Rio de Janeiro. Revista

Brasileira de Ciência do Solo. 23(2):371-382, 1999.

PONNAMPERUMA, F. N. The chemistry of submerged soils. Los Baños: Academic Press, 1972. 68p. (Advances in Agronomy, v.24).

QUÉNARD, L. et al. Lessivage as a major process of soil formation: A revisitation of existing data.

Geoderma. 167-168:135-147, 2011.

ROLIM NETO, F. C. et al. Topolitossequências do Alto Paranaíba: atributos químicos, físicos e mineralógicos. Revista Brasileira de Ciência do Solo. 33(6):17951809, 2009.

SANTOS, A. C. et al. Gênese e classificação de solos numa topossequência no ambiente de Mar de Morros do Médio Vale do Paraíba do Sul, RJ. Revista Brasileira de Ciência do Solo. 34(4):1297-1314, 2010.
SANTOS, R. D. et al. Manual de descrição e coleta de solos no campo. 5.ed. Viçosa: Sociedade Brasileira de Ciência do Solo, 2005. 100p.

SCHAETZL, R. J. Lithologic discontinuities in some soils on drumlins: theory, detection and application. Soil Science. 163(7):570-590, 1998.

SCHNEIDER, P.; KLAMT, E.; GIASSON, E. Morfologia do Solo: subsídios para caracterização e classificação de solos a campo. Guaíba: Agrolivros, 2007. 72p.

SCHNEIDER, P. et al. Solos de Porto Alegre. In: HASENACK, H. (Coord.). Diagnóstico ambiental de Porto Alegre: Geologia, Solos, Drenagem, Vegetação/ Ocupação e Paisagem. Porto Alegre: Secretaria Municipal do Meio Ambiente, 2008. p.28-43.

SCHWERTMANN, U. Differenzierung der eisenoxide des bodens durch extraction mit ammoniumoxalatlösung. Zeitschrift für Pflanzenernährung und Bodenkunde. 105(3):194-202, 1964.

SECRETARIA ESTADUAL DO MEIO AMBIENTE - SEMA. Zoneamento ambiental da silvicultura: estrutura, metodologia e resultados. Porto Alegre: Secretaria Estadual do Meio Ambiente, 2010. 137 p.

SOIL SURVEY STAFF. Keys to soil taxonomy. 11.ed. Washington DC: United States Department of Agriculture (NRCS), 2010. 346p.

TERAMOTO, E. R.; LEPSCH, I. F.; VIDALTORRADO, P. Relações solo, superfície geomórfica e substrato geológico na microbacia do Ribeirão Marins (Piracicaba-SP). Scientia Agricola. 58(2):361-371, 2001. 